\title{
EVALUATION OF Eucalyptus WOODCHIP UTILIZATION AS FUEL FOR THERMAL POWER PLANTS
}

\author{
Gabriel Browne de Deus Ribeiro ${ }^{1, \$}$ \\ https://orcid.org/0000-0003-1967-9319 \\ Mateus Alves de Magalhães ${ }^{2}$ \\ https://orcid.org/0000-0003-0465-0476 \\ Fabio Rodrigo Siqueira Batista ${ }^{3,4}$ \\ https://orcid.org/0000-0001-9669-6126 \\ Marcos Antônio da Silva Miranda ${ }^{2}$ \\ https://orcid.org/0000-0002-9998-4817 \\ Sebastião Renato Valverde ${ }^{2}$ \\ https://orcid.org/0000-0002-2489-4964 \\ Angélica de Cássia de Oliveira Carneiro ${ }^{2}$ \\ https://orcid.org/0000-0002-5992-3059
}

\begin{abstract}
This paper aims to evaluate the implications of Eucalyptus woodchip utilization as an alternative solid fuel for thermal power plants, highlighting its energy properties, power generation expenses and unit variable costs. Woodchip samples were collected from different sources and a proximate analysis was carried out in order to determine their moisture content, basic and bulk densities, ash content and higher heating value. Then, with these properties, empirical indices of a 10-megawatt thermal power plant were used to simulate the potential woodchip consumption, the forest area needed and the unit variable cost (US\$ $\cdot \mathrm{MWh}^{-1}$ ) for each sample. The results indicate that woodchip samples with lower moisture content and improved higher heating value presented: reduced woodchip consumption for the same power generation, decreased generation expenses, reduced unit variable costs and smaller Eucalyptus plantations area needed to supply the woodchip consumption. Greater energy density may result in lower transportation and storage expenses, however, does not indicate better generation performance, since it is influenced by biomass field conditions. All samples obtained satisfactory levels of ash content, which may result in lower emissions of pollutants and superior operational efficiency. Finally, all samples presented unit variable costs below the limit established by the government for participation in the regulated energy market, which might be an economic attraction for this kind of project. Therefore, Eucalyptus woodchip moisture content, higher heating value and energy density are key issues in sustainable thermal power generation and should be managed by Eucalyptus power plants in order to reach better generation performance and reduced expenses.
\end{abstract}

${ }^{1}$ Federal University of Viçosa, Department of Forest Engineering, Viçosa, MG, Brazil.

${ }^{2}$ Federal University of Viçosa, Department of Forest Engineering, Viçosa, MG, Brazil.

${ }^{3}$ CEPEL, Electrical Energy Research Center, Rio de Janeiro, RJ, Brazil.

${ }^{4}$ Pontifícia Universidade Católica do Rio de Janeiro, Department of Industrial Engineering, Rio de Janeiro, RJ, Brazil.

•Corresponding author: gabriel.deus@ufv.br

Received: 30.10.2019 Accepted: 21.01.2021 
Keywords: Eucalyptus biomass, energy properties, power generation, unit variable cost, thermal power plants, woodchip.

\section{INTRODUCTION}

Historically, Brazil has established its power generation system based on a high share of renewable sources, despite the worldwide predominance of fossil fuels (ENERDATA 2018). Until the last decade, the Brazilian power system was mostly developed on hydro generation, with a thermal generation being a necessary complement due to the possibility of critical hydrological periods, then characterizing its system as a hydrothermal system (EPE 2017). However, as part of the Brazilian government expansion policy, new renewables were introduced in its electrical matrix during the last decade, in particular wind and solar PV. As of June 2019, renewables accounted for $79,33 \%$ of the Brazilian installed capacity, in which $60,83 \%$ came from hydropower, wind $8,71 \%$, biomass $8,58 \%$, and solar photovoltaic $1,21 \%$, as presented in Table 1 (ANEEL 2019).

Table 1: Brazilian power matrix in June 2019.

\begin{tabular}{|c|c|c|c|}
\hline Source & $\mathrm{N}^{\circ}$ of Plants & MW & $\%$ of total \\
\hline Renewables & 4998 & 137250,67 & 79,33 \\
\hline Biomass & 566 & 14841,20 & 8,58 \\
\hline Agroindustry (sugarcane based) & 424 & 11482,79 & 6,64 \\
\hline Forest & 101 & 3189,35 & 1,84 \\
\hline Solid urban residues & 24 & 159,92 & 0,09 \\
\hline Liquid biofuels & 3 & 4,67 & 0,00 \\
\hline Animal residues & 14 & 4,48 & 0,00 \\
\hline Wind & 614 & 15063,89 & 8,71 \\
\hline Hydro & 1,345 & 105244,55 & 60,83 \\
\hline Solar PV & 2,472 & 2099,97 & 1,21 \\
\hline Wave electrical & 1 & 0,05 & 0,00 \\
\hline Fossil fuels & 2,439 & 25590,89 & 14,79 \\
\hline Nuclear & 2 & 1,990 & 1,15 \\
\hline Imports & - & 8,170 & 4,72 \\
\hline Total & 7,439 & $173,000,55$ & 100 \\
\hline
\end{tabular}

$\mathrm{MW}=$ megaWatt.

Even presenting a high share of renewables, according to the Ten-Year Energy Expansion Plan 2027 (EPE 2018), the hydro, wind, solar PV, sugarcane, biogas and forest biomass will be the main drivers of renewable expansion in Brazil. Until 2027, it is expected addition of 38,310 MW from those sources in its electrical matrix, representing $63 \%$ of the system expansion. One of the challenges faced by systems with a high share of renewables is that most of them are non-dispatchable sources, such as wind and solar PV. It means that the system may not have the capacity to produce enough electricity to reach its demand due to the lack of wind or solar radiation at the same moment the demand happens (Morato et al. 2018). For this reason, it is comprehended that Brazil must also invest in renewable fuels that are not intermittent, i.e., may be dispatched whenever there is a scarcity of other sources, and which are relatively inexpensive (Lamas and Giacaglia 2013). In this context, the use of the planted forest is presented as an alternative, since Brazil is a major Eucalyptus producer with high productivity rates on an industrial scale. In 2019, the total area of planted forests in Brazil was 9,0 million hectares, of which 6,97 million hectares were of Eucalyptus plantations. Those were mainly concentrated in Minas Gerais, São Paulo and Mato Grosso do Sul states. Brazil is also recognized for its high forest productivity: in the last five years, the average Eucalyptus productivity rate was $35,7 \mathrm{~m}^{3} \cdot \mathrm{ha}^{-1}$, and in the last 10 years, the average growth rate of Eucalyptus plantations in Brazil was 4,21\% p.a., which is expected to remain stimulated by pulp and energy sectors (IBÁ 2020).

In the actual scenario, thermal power plants (TPPs) using forest biomass are increasing their participation in cogeneration and industrial-specific projects, through the utilization of Eucalyptus woodchips, with a high degree of national content and reduced operational costs (Deboni et al. 2019, Miranda et al. 2017). In addition, it can be considered that woodchips present technical improvements, such as i) high degree of mechanization, from the harvest until its combustion in power plants; ii) almost complete use of the trees for energy (all aerial components) in well-managed forest plantations; iii) better steam quality when compared to firewood, as woodchips allow uniform burning and flow in thermal systems (Do et al. 2014, Ignacio et al. 2019). 
Most of the projects are being developed with a small installed capacity (less than $100 \mathrm{MW}$ ), which allows its development where the demand is located or via distributed generation. This strategy seems to be necessary since some existing woodchip TPPs have been facing technical and operational issues (e.g., low forest productivity rate, insufficient woodchip volume for power demand, lack of knowledge of woodchip fuel parameters, etc.) (EPE 2018).

Furthermore, despite the potential of Eucalyptus woodchip for power generation, there are few studies that address its use and its fuel properties for thermal power generation. According to two Brazilian institutional reports (CGEE 2015) and (IAB 2015), the main studies are related to Eucalyptus for charcoal production aimed at the steel industry, and Eucalyptus use for boilers to meet industrial steam demand, as can be observed in previous studies (De Oliveira Vilela et al. 2014, Carneiro et al. 2014, Miranda et al. 2017). It should also be noted that there is a lack of knowledge on part of the electrical industry about the characteristics of Eucalyptus woodchip and its use in the combustion process for power generation. Therefore, this work aims to address some of these issues, as a way to track an even cleaner energy mix in Brazil and worldwide.

In this context, this study goals to characterize the utilization of Eucalyptus woodchip as an alternative solid fuel for thermal power plants, highlighting its fuel properties and power generation expenses. The paper's main contributions include the following areas: i) for the government: considering that there are few studies related to the use of Eucalyptus woodchips in power generation, these results should be used to address regulatory issues related to the use of a non-intermittent fuel; ii) for investors: the energy properties obtained may be used to simulate the project's viability as well as to point out some fuel features that may improve power generation efficiency; and iii) for forest producers: these findings are relevant for forest producers in order to trade biomass for power generation with better fuel quality.

\section{MATERIALS AND METHODS}

\section{Sampling and samples preparation}

Five different Eucalyptus woodchip samples commonly used as fuel in boilers were analysed in this study (Figure 1). All the samples were obtained from different companies that use woodchips for steam and power generation. Samples 1 and 2 came from distinct Eucalyptus plantations located in Viçosa's region (Minas Gerais state) and originated from clones of Eucalyptus hybrids E. urophylla $\mathrm{x}$ E. grandis, harvested at seven years old. Samples 3, 4 and 5 came from distinct plantations in Rondonópolis' region (Mato Grosso state), and originated from clones of Eucalyptus hybrids E. urophylla x E. grandis, harvested at seven years old as well. All samples were randomly selected from their respective piles of woodchips. The drying period informed by the companies was around 90-120 days for all the samples. Sampling and sample preparation was conducted in order to be representative of the combustion process in thermal power generation.

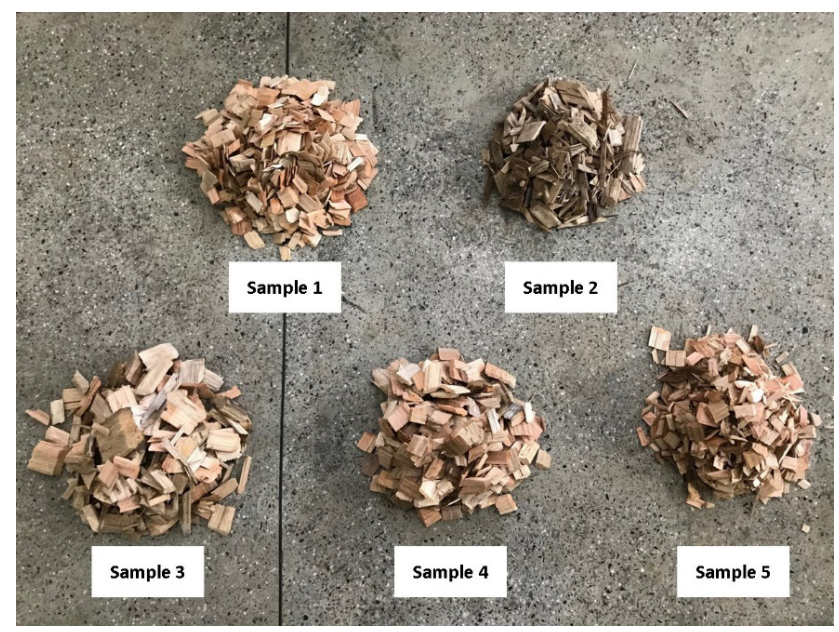

Figure 1: Collected samples of Eucalyptus woodchips used in this study. 


\section{Characterization of the collected samples}

Samples characterization followed the standardized methods that conduct to consistent and accurate evaluation of fuel properties. Moisture content (\%), bulk density $\left(\mathrm{kg} \cdot \mathrm{m}^{-3}\right)$ and ash content $(\%)$ were determined following standards DIN EN 14774-2 (2010a), DIN EN 15103 (2010c), DIN EN 14775 (2012), and the basic density $\left(\mathrm{kg} \cdot \mathrm{m}^{-3}\right)$ according to (Vital 1984). Higher heating value (HHV), expressed in $\mathrm{MJ} \cdot \mathrm{kg}^{-1}$, was achieved with an IKA ${ }^{\circledR \top M}$ C200 calorimeter and followed the standard DIN EN 14918 (2010b). Net heating value (NHV), expressed in $\mathrm{MJ} \cdot \mathrm{kg}^{-1}$, was estimated from the higher heating value using Equation 1, according to standard DIN EN 14918 (2010b).

$$
N H V(\text { constant pressure })=(\mathrm{HHV}-212,2 \times \mathrm{H}-0,8 x(O+\mathrm{N}) \times(1-0,01 x \mathrm{M})-(24,43 x \mathrm{M})
$$

Where: $\mathrm{NHV}$ (constant pressure) $=$ net heating value in constant pressure $\left(\mathrm{J} \cdot \mathrm{g}^{-1}\right)$; HHV $=$ higher heating value $\left(\mathrm{J} \cdot \mathrm{g}^{-1}\right) ; \mathrm{H}, \mathrm{O}, \mathrm{N}=$ hydrogen, oxygen and nitrogen, respectively, in percentage $(\%) ; \mathrm{M}=$ hygroscopic equilibrium moisture content, wet basis, in percentage (\%); Constants: 212,20 = water vaporization energy (constant pressure) at $25^{\circ} \mathrm{C}$ is $44,01 \mathrm{~kJ} \cdot \mathrm{mol}^{-1}$. This corresponds to $218,3 \mathrm{~J} \cdot \mathrm{g}^{-1}$ for $1 \%$ hydrogen $(\mathrm{m} / \mathrm{m})$ or $24,43 \mathrm{~J} \cdot \mathrm{g}^{-1}$ for $1 \%$ of moisture $(\mathrm{m} / \mathrm{m})$ in the sample.

From $\mathrm{kcal} \cdot \mathrm{kg}^{-1}$ to $\mathrm{J} \cdot \mathrm{g}^{-1}$, it was considered that a $\mathrm{kcal} \cdot \mathrm{kg}^{-1}$ corresponds to $4,184 \mathrm{~J} \cdot \mathrm{g}^{-1}$. The energy density, expressed in GJ $\cdot \mathrm{m}^{-3}$, was obtained by the multiplication of the sample's basic density $\left(\mathrm{kg} \cdot \mathrm{m}^{-3}\right)$ and their respective HHV $\left(\mathrm{MJ}^{\mathrm{kg}} \mathrm{kg}^{-1}\right)$. All parameters were determined in the Panels and Wood Energy Laboratory (LAPEM), Department of Forestry Engineering, Federal University of Viçosa, Brazil. All determinations were as received, i.e., on a wet basis.

\section{Statistical analysis}

The experiment was analysed according to a completely randomized design, with five different Eucalyptus woodchip samples and three replicates, totaling 15 sampling units for each energy property. Data normality for all variables was assessed by Lilliefors' test, and Cochran and Bartlett's test was performed for homogeneity of variances. The analysis of variance (ANOVA) was performed and whenever significant differences were observed, the treatments were compared by Tukey's test at $5 \%$ of probability level. Statistical analyses were implemented in the Statistica program (Statsoft 2007).

\section{Woodchip consumption and required forest area}

In this study, several empirical parameters were used to evaluate the fuel consumption that each woodchip sample would represent. These parameters were obtained with ICAVI Caldeiras S/A (ICAVI 2019), a Brazilian company that specialized in the development, construction and, assistance of boilers and thermal power projects. All the empirical indices may be considered a mean of what ICAVI Caldeiras S/A observes and/or determines on its business. For the study's purpose, a thermal power project was developed using empirical parameters in order to simulate steam production, power generation and the woodchip consumption required for this production. The main characteristics of this project are:

i) gross installed capacity of $10 \mathrm{MW}$, which is close to the average installed capacity of the woodchips thermal power plants currently operating in Brazil: about $8 \mathrm{MW}$, according to the Brazilian Electricity Regulatory Agency (ANEEL 2019);

ii) adoption of Rankine steam cycle technology, the most used in Brazil and considered a well-developed technology. Rankine is comprehended as a simple technological route based on the use of water/steam as transportation fluid and energy storage. In this process (Figure 2), direct combustion of forest biomass occurs in a boiler for the generation of the superheated steam, which, in turn, feeds steam turbines for power generation of thermal origin (Lora and Andrade 2009). 


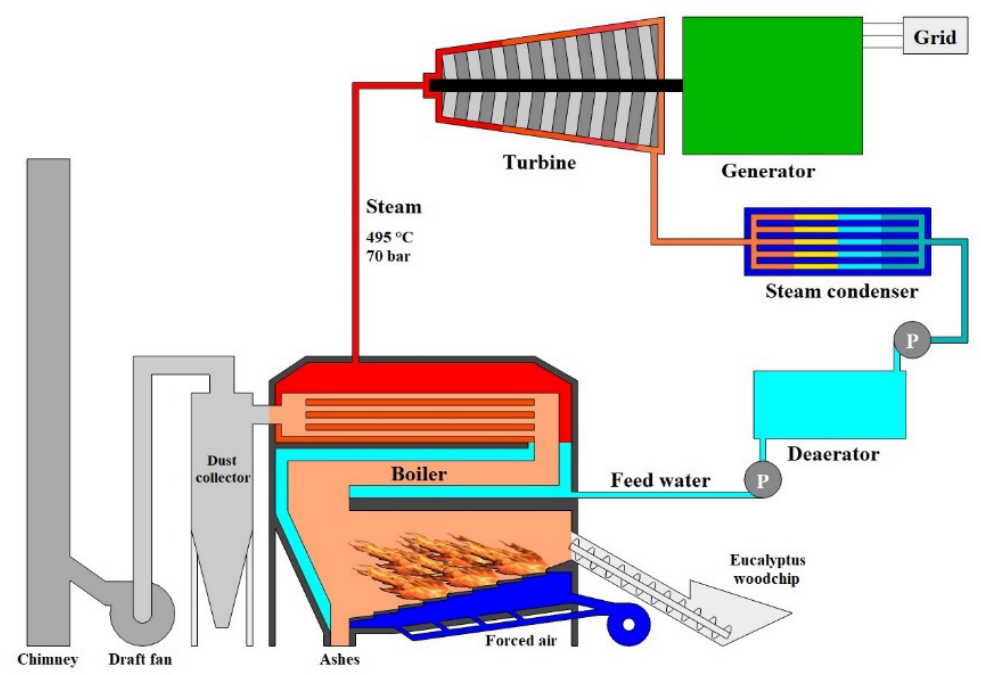

Figure 2: Thermal power plant scheme. Source: own elaboration.

Table 2 presents the empirical parameters; the equations used to reach the woodchip consumption and the forest area needed; and the acronyms used in each equation. Two forest parameters were considered for calculations: Eucalyptus mean annual volume increment (MAI) equal to $35 \mathrm{~m}^{3} \cdot \mathrm{ha}^{-1} \cdot \mathrm{year}^{-1}$, and forest stands cut age of 700 years, both are considered the Brazilian average, according to the Brazilian Tree Industry Annual Report (IBÁ 2020). The other forest parameters used in calculations were determined in Laboratory. The fuel consumption calculation was made considering the use of all the aerial Eucalyptus tree volume, since in Brazil Eucalyptus plantations for energy purposes are entirely managed for it.

Table 2: Empirical parameters and calculations.

\begin{tabular}{|c|c|c|c|c|c|c|c|}
\hline Code & Data & Unit & Value & Code & Calculations & Unit & Equations \\
\hline & $\begin{array}{c}\text { Assumed } \\
\text { parameters }\end{array}$ & & & - & Higher heating value & $\mathrm{kcal} \cdot \mathrm{kg}^{-1}$ & Lab \\
\hline- & $\begin{array}{c}\text { Gross installed } \\
\text { power }\end{array}$ & MW & 10 & I & Net heating value & $\mathrm{kcal} \cdot \mathrm{kg}^{-1}$ & Equation 1 \\
\hline $\mathrm{A}$ & Steam production & $\mathrm{kg} \cdot \mathrm{h}^{-1}$ & 40000 & $\mathrm{~J}$ & Basic density & $\mathrm{kg} \cdot \mathrm{m}^{-3}$ & $\mathrm{Lab}$ \\
\hline- & Boiler pressure & bar & 70 & $\mathrm{~K}$ & Bulk density & $\mathrm{kg} \cdot \mathrm{m}^{-3}$ & $\mathrm{Lab}$ \\
\hline- & $\begin{array}{c}\text { Superheated steam } \\
\text { temperature }\end{array}$ & ${ }^{\circ} \mathrm{C}$ & 495 & $\mathrm{~L}$ & Moisture content & $\%$ & $\mathrm{Lab}$ \\
\hline $\mathrm{B}$ & Boiler yield & $\%$ & 0,85 & & Fuel consumption & & \\
\hline $\mathrm{C}$ & Steam enthalpy & $\mathrm{kcal} \cdot \mathrm{kg}^{-1}$ & 811,86 & $\mathrm{M}$ & Delta enthalpy & $\mathrm{kcal} \cdot \mathrm{kg}^{-1}$ & $=\mathrm{C}-\mathrm{D}$ \\
\hline $\mathrm{D}$ & Water enthalpy & $\mathrm{kcal} \cdot \mathrm{kg}^{-1}$ & 105 & $\mathrm{~N}$ & Total steam (hour) & $\mathrm{kcal} \cdot \mathrm{h}^{-1}$ & $=A^{*} \mathrm{M} / \mathrm{B}$ \\
\hline $\mathrm{E}$ & Generation factor & $\begin{array}{c}\mathrm{kg} \\
\text { steam } \cdot \mathrm{MWh}^{-1}\end{array}$ & 4500 & $\mathrm{O}$ & Fuel consumption (wet) & $\mathrm{kg} \cdot \mathrm{h}^{-1}$ & $=\mathrm{N} / \mathrm{I}$ \\
\hline \multirow[t]{5}{*}{$\mathrm{F}$} & Work regime & $\mathrm{h} \cdot$ year $^{-1}$ & 8322 & $\mathrm{P}$ & Fuel consumption (wet) & $\mathrm{kg} \cdot$ year $^{-1}$ & $=\mathrm{O} * \mathrm{~F}$ \\
\hline & Daily & $h \cdot$ day $^{-1}$ & 24 & Q & $\begin{array}{l}\text { Forest area required } \\
\text { (total) }\end{array}$ & ha & $=\mathrm{P} /\left(\mathrm{H}^{*} \mathrm{~J} *(1+\mathrm{L})\right.$ \\
\hline & Annual & days $\cdot$ year $^{-1}$ & 365 & & $\begin{array}{c}\text { Forest area required } \\
\text { (annual) }\end{array}$ & ha. year ${ }^{-1}$ & $=\mathrm{Q} / \mathrm{G}$ \\
\hline & Availability factor & $\%$ & 0,95 & & $\begin{array}{l}\text { Effective fuel } \\
\text { consumption }\end{array}$ & \begin{tabular}{|c|}
$\begin{array}{c}\mathrm{kg} \text { wchp } \\
\text { steam }^{-1}\end{array}$ \\
\end{tabular} & $=\mathrm{M} / \mathrm{I} / \mathrm{B}$ \\
\hline & Forest parameters & & & & Power generation & & \\
\hline $\mathrm{G}$ & Stands cut age & years & 7 & $\mathrm{R}$ & Maximum energy & MWh & $=\mathrm{A} / \mathrm{E}$ \\
\hline \multirow[t]{2}{*}{$\mathrm{H}$} & $\begin{array}{c}\text { Mean annual } \\
\text { increment }\end{array}$ & $\mathrm{m}^{3} \cdot \mathrm{ha}^{-1} \cdot$ year $^{-1}$ & 35 & $\mathrm{~S}$ & $\begin{array}{c}\text { Fuel consumption } \\
\text { /MWh }\end{array}$ & $\mathrm{kg} \mathrm{MWh}^{-1}$ & $=\mathrm{O} / \mathrm{R}$ \\
\hline & & & & & $\begin{array}{c}\text { Fuel consumption } \\
\text { /MWh }\end{array}$ & $\mathrm{m}^{3} \mathrm{MWh}^{-1}$ & $=\mathrm{S} / \mathrm{K}$ \\
\hline
\end{tabular}

For fuel consumption calculation, HHV and NHV were expressed in $\mathrm{kcal} \cdot \mathrm{kg}^{-1}$. From $\mathrm{J} \cdot \mathrm{g}^{-1}$ to $\mathrm{kcal} \cdot \mathrm{kg}^{-1}$, it was considered that a $\mathrm{kcal} \cdot \mathrm{kg}^{-1}$ corresponds to $4,184 \mathrm{~J} \cdot \mathrm{g}^{-1}$. 
The effective fuel consumption index ( $\mathrm{kg}$ woodchip $\cdot \mathrm{kg} \mathrm{steam}^{-1}$ ) represents the efficiency of the fuel employed in the thermal process, i.e., the less this index, the smaller the amount of fuel required to generate the same quantity of energy.

\section{Power generation expenses and unit variable cost}

Each sample's parameters were simulated in the thermal power project and resulted in five different woodchip consumption scenarios, as well as distinct power generation expenses and unit variable costs (UVCs). UVC is the TPP's operational cost, which mostly represents the fuel costs (EPE 2017) and is expressed in $\mathrm{US} \$ \mathrm{MWh}^{-1}$. For example, in the Brazilian power sector, the UVC is used by the System Operator in order to define the dispatch's merit order of thermal power plants and to compose the cost-benefit index of such plants that sell energy in the Brazilian Regulated Market, among other uses (EPE 2017). Since 2017, a UVC cap was established by the Brazilian government to allow a TPP to sell energy in the Regulated Market. This market represents around $70 \%$ of the Brazilian consumption (CCEE 2019). Such cap is equal to $280 \mathrm{R} \$ \cdot \mathrm{MWh}^{-1}$. Conversion to US dollars considered the April 2019 mean exchange rate: 3,90 BRL·US\$ ${ }^{-1}$ (BCB 2019), thus the UVC cap used in this study is $71,87 \mathrm{US} \$ \mathrm{MWh}^{-1}$. Then, all the financial variables were calculated in US dollars. The unit variable cost is determined as Equation 2, and fuel expenses as showed in Equation 3:

$$
U V C=C_{\text {fuel }}+C_{O \& M}
$$

Where: $\mathrm{C}_{\text {fuel }}=$ represents the fuel expenses (annual-basis), expressed in US\$; $\mathrm{C}_{\mathrm{O \& M}}=$ represents the operational and maintenance expenses (annual-basis), in US\$. $\mathrm{C}_{\mathrm{O \& M}}$ was fixed at 2,57 $\mathrm{US} \$ \cdot \mathrm{MWh}^{-1}\left(10 \mathrm{R} \$ \mathrm{MWh}^{-1}\right)$ which is a proxy, and then multiplied by the annual maximum power generation to reach the annual value.

$$
C_{\text {fuel }}=i x\left(\frac{G_{\max }}{h_{y}}\right)
$$

Where: $i=$ Conversion Factor necessary to transform the fuel price in US\$ $\cdot \mathrm{MWh}^{-1}$. This conversion factor is expressed by the Equation $4 ; \mathrm{G}_{\max }=$ annual maximum power generation; $\mathrm{h}_{\mathrm{y}}=$ heat yield or efficiency. In this study heat yield was assumed in $28 \%$.

$$
i=\frac{\text { Fuel price }}{\left(\frac{N H V}{3600}\right)}
$$

Where: Fuel price $=$ The assumed woodchip price was 46,20 US\$ $\cdot \mathrm{t}^{-1}$. In Minas Gerais state woodchips have been commercialized at $180 \mathrm{BRL} \cdot \mathrm{t}^{-1}$ (CIFlorestas 2018); and 3600 is a conversion factor from $\mathrm{MJ} \cdot \mathrm{t}^{-1}$ to $\mathrm{MWh} \cdot \mathrm{t}^{-1}$.

To obtain the UVC in US\$ $\cdot \mathrm{MWh}^{-1}$, the annual value in US\$ was divided by the maximum power generation in $\mathrm{MWh} \cdot \mathrm{year}^{-1}$.

\section{RESULTS AND DISCUSSION}

\section{Woodchips energy characterization}

The results of energy characterization per sample are presented in Table 3. 
Table 3: Mean fuel properties values for the Eucalyptus woodchip samples.

\begin{tabular}{|c|c|c|c|c|c|c|}
\hline Data & Unit & Sample 1 & Sample 2 & Sample 3 & Sample 4 & Sample 5 \\
\hline Basic density & $\mathrm{kg} \cdot \mathrm{m}^{-3}$ & $530,42 \mathrm{a}$ & $544,34 \mathrm{a}$ & $546,60 \mathrm{a}$ & $543,28 \mathrm{a}$ & $449,47 \mathrm{~b}$ \\
\hline $\mathrm{HHV}$ & $\mathrm{MJ} \cdot \mathrm{kg}^{-1}$ & $19,53 \mathrm{a}$ & $19,41 \mathrm{a}$ & $19,35 \mathrm{a}$ & $19,67 \mathrm{a}$ & $19,73 \mathrm{a}$ \\
\hline Energy density & $\mathrm{GJ} \cdot \mathrm{m}^{-3}$ & 10,36 & 10,56 & 10,58 & 10,69 & 8,87 \\
\hline Ash content & $\%$ & $0,46 \mathrm{ab}$ & $0,54 \mathrm{a}$ & $0,41 \mathrm{ab}$ & $0,35 \mathrm{~b}$ & $0,39 \mathrm{ab}$ \\
\hline Field/practical conditions & & & & & & \\
\hline $\begin{array}{c}\text { Moisture content - wet } \\
\text { basis }\end{array}$ & $\%$ & $25,41 \mathrm{c}$ & $22,88 \mathrm{c}$ & $31,82 \mathrm{~b}$ & $32,72 \mathrm{~b}$ & $38,47 \mathrm{a}$ \\
\hline Bulk density & $\mathrm{kg} \cdot \mathrm{m}^{-3}$ & $261,13 \mathrm{~b}$ & $238,30 \mathrm{c}$ & $236,81 \mathrm{c}$ & $253,68 \mathrm{~b}$ & $283,57 \mathrm{a}$ \\
\hline NHV & $\mathrm{MJ} \cdot \mathrm{kg}^{-1}$ & 12,98 & 13,41 & 11,53 & 11,56 & 10,40 \\
\hline
\end{tabular}

Means followed by the same letters within a row do not statistically differ from each other by the Tukey's test at $5 \%$ of significance.

As may be observed in Table 3, the obtained values for basic density varied between $449,47 \mathrm{~kg} \cdot \mathrm{m}^{-3}$ ( $\mathrm{sam}$ ple 5) and $546,60 \mathrm{~kg} \cdot \mathrm{m}^{-3}$ (sample 3), and sample 5 basic density was significantly different from the others. For higher heating value, the obtained values varied between $19,35 \mathrm{MJ} \cdot \mathrm{kg}^{-1}$ (sample 3 ) and $19,73 \mathrm{MJ} \cdot \mathrm{kg}^{-1}(\mathrm{sample}$ 5 ) and no statistical differences were observed between the samples. All the obtained values reside within the normal range for Brazilian Eucalyptus genres, which is $450 \mathrm{~kg} \cdot \mathrm{m}^{-3}-550 \mathrm{~kg} \cdot \mathrm{m}^{-3}$ for basic density and 18,5 $\mathrm{MJ} \cdot \mathrm{kg}^{-1}-20,0 \mathrm{MJ} \cdot \mathrm{kg}^{-1}$ for HHV, according to Castro et al. (2016) and Magalhães et al. (2017).

The energy density, which was obtained by the multiplication of HHV and the basic density, indicates the potential of energy generation per sample and also the viability of transport and storage of biomasses. As this calculation is made on a dry-basis, it excludes the influence of the moisture content, and represents the fuel property of the genetic material. In this way, sample 4 would be more efficient in the energy generation, being able to supply up to $10,69 \mathrm{GJ} \cdot \mathrm{m}^{-3}$. In contrast, the lowest value was observed in sample $5\left(8,87 \mathrm{GJ} \cdot \mathrm{m}^{-3}\right)$. For this sample, even presenting the highest HHV, its lower energy density was influenced by its reduced basic density, making sample 5 possibly the most expensive in terms of storage, transport and handling, compared to the other samples. This point can also be observed in Martinez et al. (2019), for biomass residues, where the authors have observed that the increased the energy density, the reduced the transport and handling costs of the biomasses. The results of energy density obtained in this work are relatively similar to those found by Magalhães et al. (2017) when studying Eucalyptus genetic materials for energy.

For the ash content, the obtained values varied between $0,35 \%$ (sample 4 ) and $0,54 \%$ (sample 2) and statistical differences were observed between samples 4 and 2. The results of this study can be considered valuable when compared with other studies for Eucalyptus (Ignacio et al. 2019, Almeida et al. 2010). For Eucalyptus urosemente woodchips, Ignacio et al. (2019) observed values between 1,05\% and 1,54\%. The authors considered that the presence of bark in the extracted samples increased the ash content. Fernández et al. (2012a) also observed higher ash content for Eucalyptus $(1,9 \% \pm 0,9 \%)$, reaching values over $30 \%$ higher than expected in the bibliography.

It is also important to note that almost all the samples in this study presented ash content below $0,50 \%$, which may be considered satisfactory in relation to gases emissions and operational efficiency, since ash content is related to the reduction of the HHV, to residues generation in the combustion process and, depending on the composition, to the corrosion or formation of deposits in boilers (Deboni et al. 2019, Fernández et al. 2012b).

The moisture content varied between 22,88 \% (sample 2) and 38,47 \% (sample 5) and statistical differences were observed between the samples. These variations directly impacted samples NHV, which varied between $10,40 \mathrm{MJ} \cdot \mathrm{kg}^{-1}$ (sample 5) and 13,41 MJ $\mathrm{kg}^{-1}$ (sample 2). The highest NHVs were observed from samples 2 and 1 , and the lowest from samples 5 and 3 . It is important to mention that under field/practical conditions, it is normal to observe woodchip moisture content around $40-50 \%$ due to local weather and humidity variations.

Bulk density is an essential factor that may influence the economic viability of biomass materials utilization, since it affects transport costs. In this study, bulk density varied between $236,81 \mathrm{~kg} \cdot \mathrm{m}^{-3}$ (sample 3 ) and $283,57 \mathrm{~kg} \cdot \mathrm{m}^{-3}$ (sample 5), being directly influenced by the basic density and moisture content of the biomass. Significant differences were observed between the samples. 
Concerning the combustion process, it is desirable for woodchips to present as reduced moisture content as possible, which can provoke greater NHV. In these terms, samples 2 and 1, both from Viçosa's region, presented the greatest net heating values and lowest moisture contents, respectively, which should impact the fuel consumption and project operational expenses. On the other hand, samples 5, 3 and 4, from Rondonópolis' region, presented the lowest net heating values due to the highest moisture contents, and although they have demonstrated some decreased fuel properties, when compared to Viçosa' samples, they should not be discarded since their other indicators are satisfactory. For example, sample 4 showed the highest energy density, which may reduce its transport and handling costs.

\section{Estimated woodchip consumption and forest area required}

The simulated values are presented in Table 4, considering the maximum energy generation for this thermal power project, that was $73973,33 \mathrm{MWh} \cdot \mathrm{year}^{-1}$.

Table 4: Estimated Eucalyptus woodchip consumption by sample.

\begin{tabular}{|c|c|c|c|c|c|}
\hline Fuel consumption & Sample 1 & Sample 2 & Sample 3 & Sample 4 & Sample 5 \\
\hline $\mathrm{t} \cdot \mathrm{h}^{-1}$ & 10,72 & 10,38 & 12,07 & 12,03 & 13,38 \\
\hline $\mathrm{m}^{3} \cdot \mathrm{h}^{-1}$ & 41,06 & 43,55 & 50,95 & 47,44 & 47,18 \\
\hline $\mathrm{kg} \mathrm{wchp} \cdot \mathrm{kg} \mathrm{steam}^{-1}$ & 0,268 & 0,259 & 0,302 & 0,301 & 0,334 \\
\hline $\mathrm{t} \cdot \mathrm{MWh}^{-1}$ & 1,21 & 1,17 & 1,36 & 1,35 & 1,51 \\
\hline $\mathrm{m}^{3} \cdot \mathrm{MWh}^{-1}$ & 4,62 & 4,90 & 5,73 & 5,34 & 5,31 \\
\hline $\mathrm{t} \cdot \mathrm{year}^{-1}$ & 89238,01 & 86373,76 & 100415,70 & 100149,96 & 111344,44 \\
\hline $\begin{array}{c}\text { Eucalyptus } \text { planted } \\
\text { forest area }\end{array}$ & & & & & \\
\hline ha & 3832,93 & 3689,42 & 3981,86 & 3968,34 & 5111,35 \\
\hline ha $\cdot$ year & 547,56 & 527,06 & 568,84 & 566,91 & 730,19 \\
\hline
\end{tabular}

All sample' parameters were simulated for the same energy production as well as the same empirical generation indices. As can be observed, the smallest fuel consumption, in $\mathrm{t} \cdot \mathrm{h}^{-1}$, occurred when using samples 2 and 1, which were those with the highest NHVs and lowest moisture content, both from Viçosa's region and from different companies. The highest fuel consumption occurred when simulated for sample 5, the one with the highest moisture content and lowest NHV.

In cubic meters per hour, the consumption varied between 41,06 (using sample 1) and 50,95 (using sample 3 ). This difference occurred due to the different bulk density observed in each case, as sample 3 presented the lowest bulk density. In terms of woodchip per kg of steam, simulated values for the use of sample 2 presented again the lowest relationship $(0,259)$ and the highest occurred when using sample $5(0,334)$. This index means that when using sample 2 the project should need less fuel to generate the same amount of steam, and consequently, power, than using other samples, since sample 2 reported the greatest NHV and the smallest moisture content.

Regarding woodchip tons per MWh and cubic meters per MWh, the relationship observed above remained: the project simulated with sample 2 presented the lowest fuel consumption $\left(1,17 \mathrm{t} \cdot \mathrm{MWh}^{-1}\right)$ and with sample 5 the highest consumption $\left(1,51 \mathrm{t} \cdot \mathrm{MWh}^{-1}\right)$. In cubic meter per $\mathrm{MWh}$, sample 1 presented the lowest $\left(4,62 \mathrm{~m}^{3} \cdot \mathrm{MWh}^{-1}\right)$ and sample 3 the highest $\left(5,73 \mathrm{~m}^{3} \cdot \mathrm{MWh}^{-1}\right)$. On a year-basis, sample 2 would be consumed 86373,76 woodchip tons and with sample 5 it was observed the highest amount needed: 111344,44 tons $(28,91$ $\%$ more than sample 2). These results demonstrate that greater NHV - which normally occurs when the sample presents reduced moisture content and elevated HHV- represents a valuable quality for thermal energy production.

For the required forest area analysis, the project simulated with samples 2 and 1 (separately) showed the lowest level of forest area required 3689,42 and 3832,93 hectares (in total) respectively, and with sample 5 the greatest: 5111,35 hectares. In this case, two fuel properties influenced the calculation: moisture content and basic density. Despite not having the highest basic density (sample 3 is the highest), sample 2 presented 
the smallest moisture content, which directly impacted the required area. Similar results may be observed in (Miranda et al. 2017). Viçosa's region (Minas Gerais state), is composed of 20 municipalities and is recognized for its forestry and agricultural vocation. According to data from the Brazilian Institute of Geography and Statistics, this region has 23833 hectares of Eucalyptus (IBGE 2017). With that, it is possible to infer that this kind of project is able to demand a reasonable portion of the existing forest biomass of this region: $15,5 \%$ using sample 2 fuel properties and $16,1 \%$ for sample 1, considering the maximum power generation. Comparatively, Rondonópolis' region (Mato Grosso state) is composed of 10 municipalities and is also known for its forestry importance. This region actually has 27347 hectares of Eucalyptus (IBGE 2017). Using the fuel properties of the samples from there, it may be pointed that sample 3 would demand 14,6 \% of the region's forest plantations; sample 4: 14,5\%; and sample 5: 18,7\%.

Therefore, a small to the medium-sized thermal power plant for these regions may be an interesting economic activity. It also may be noted that projects of this size would not necessarily need to buy or lease land to plant forests, and may maintain supply with local producers. Even considering that part of this forest stock is unavailable, these projects would not have to travel long distances to purchase wood, which corresponds to an advantage for the business.

Another point to be discussed is related to the technical empirical indices used in this study and how they can be supported. Although some indices are considered Eucalyptus-exclusive for the combustion process, some empirical parameters can be observed in studies: the power-to-heat ratio of $4500 \mathrm{~kg} s t e a m \cdot \mathrm{MWh}^{-1}$ (Nzotcha and Kenfack 2019); the overall efficiency of 85,00 \% (Stoppato 2012); the steam delta enthalpy for fuel consumption (Buchmayr et al. 2015); the heat yield of $28,00 \%$ (Saidur et al. 2011).

\section{Estimated power generation expenses and unit variable cost}

Simulated expenses and UVC for each sample are presented in Table 5.

Table 5: Estimated annual generation expenses per sample.

\begin{tabular}{|c|c|c|c|c|c|c|}
\hline Generation expenses & Unit & Sample 1 & Sample 2 & Sample 3 & Sample 4 & Sample 5 \\
\hline Conversion factor $(i)$ & US\$·MWh ${ }^{-1}$ & 12,81 & 12,40 & 14,42 & 14,38 & 15,99 \\
\hline Fuel expenses $\left(C_{\text {fuel }}\right)$ & $\begin{array}{c}\text { US\$ } \\
\text { MM·year }\end{array}$ & 3,385 & 3,277 & 3,809 & 3,799 & 4,224 \\
\hline $\mathrm{O} \& \mathrm{M}\left(\mathrm{C}_{\mathrm{O} \& \mathrm{M}}\right)$ & $\begin{array}{c}\text { US\$ } \\
\text { MM·year }\end{array}$ & 0,190 & 0,190 & 0,190 & 0,190 & 0,190 \\
\hline Total expenses & $\begin{array}{c}\text { US\$ } \\
\text { MM·year }\end{array}$ & 3,575 & 3,467 & 3,999 & 3,989 & 4,414 \\
\hline Unit Variable Cost & US\$.MWh ${ }^{-1}$ & 48,33 & 46,86 & 54,06 & 53,93 & 59,67 \\
\hline
\end{tabular}

Since the conversion factor is dependent on the NHV, this factor followed the results already discussed. The use of sample 2 presented the lowest total annual expenses, and sample 5 the highest. The obtained values varied between 3,467 US\$ million year $^{-1}$ (using sample 2) and 4,414 US\$ million·year ${ }^{-1}$ (using sample 5). These results were already expected since sample 2 was responsible for the smallest amount of fuel to generate the energy proposed for this project, and sample 5 required the highest amount.

As the sample 2' project required less fuel to generate the same level of energy, this sample demonstrated the best results regarding the unit variable cost: $46,86 \mathrm{US} \$ \cdot \mathrm{MWh}^{-1}$. The worst economic results were obtained when using sample 5: UVC of 59,67 US\$ $\cdot \mathrm{MWh}^{-1}$. All samples' UVCs were below the cap established by the Brazilian government for new projects in the regulated market $\left(71,87 \mathrm{US} \$ \mathrm{MWh}^{-1}\right)$. In this way, the project would participate in the regulated market using these different samples. Thus, it is the investor's responsibility to purchase woodchips with fuel parameters that keep the project's viability. Working efficiently with these parameters can lead to a reduction of the risks in the face of fuel price fluctuations. Therefore, from the investor and forest producer point of view, forest plantations with better quality for energy can positively affect the operations of the plant, the economics of the projects and the remuneration for the producer. 


\section{CONCLUSIONS}

This work characterized fuel properties of five different Eucalyptus woodchip samples obtained in two distinct Brazilian states, taking into account its possible use as fuel for a thermal power plant connected to the national system.

Several indicators were calculated and a complete methodology was exposed, bringing relevant information that may be replicated in other forest biomass studies, and that may contribute to improving the interest in a non-intermittent source for the Brazilian power sector. However, some limitations might be observed, such as the limits of the sampling method for the identification of the five samples; the standardization of all empirical coefficients and energy properties for the full operational year, which requires further studies with real operational systems.

The work results indicate that woodchip samples with lower moisture content and improved higher heating value presented: reduced woodchip consumption for the same power generation, decreased generation expenses, reduced unit variable costs and smaller Eucalyptus plantations area needed to supply the woodchip consumption. Greater energy density may result in lower transportation and storage expenses, however, does not indicate better generation performance, since it is influenced by biomass field conditions. All samples obtained satisfactory levels of ash content, which may result in lower emissions of pollutants and superior operational efficiency. Finally, all samples presented unit variable costs below the limit established by the government for participation in the regulated energy market, which might be an economic attraction for this kind of project.

Therefore, Eucalyptus woodchip moisture content, higher heating value, and energy density are key issues in sustainable thermal power generation and should be managed by Eucalyptus power plants in order to reach better generation performance and reduced expenses.

\section{ACKNOWLEDGMENTS}

The authors are grateful to the Brazilian Coordination for the Improvement of Higher Education Personnel (CAPES) for the financial support provided (Doctor' science scholarship for the senior author - Code: 88882.437314/2019-01). The authors would also like to acknowledge the Laboratory of Panels and Wood Energy from the Federal University of Viçosa.

\section{REFERENCES}

Almeida, G.; Brito, J.O.; Perré, P. 2010. Alterations in Energy Properties of Eucalyptus Wood and Bark Subjected to Torrefaction: The Potential of Mass Loss as a Synthetic Indicator. Bioresour Technol 101(24): 9778-9784. https://doi.org/10.1016/j.biortech.2010.07.026

Agência Nacional de Energia Elétrica. ANEEL. 2019. Capacidade de Geração do Brasil. ANEEL: Brasília, Brasil. https://www.aneel.gov.br/sigaBanco Central do Brasil. BCB. 2019. Taxas de câmbio. BCB: Brasília, Brasil. https://www.bcb.gov.br/en/\#!/n/EXCHANGERATES

Buchmayr, M.; Gruber, J.; Hargassner, M.; Hochenauer, C. 2015. Experimental Investigation of the Primary Combustion Zone during Staged Combustion of Wood-Chips in a Commercial Small-Scale Boiler. Biomass Bioenerg 81: 356-363. https://doi.org/10.1016/j.biombioe.2015.07.016

Carneiro, A.C.O.; Castro, A.F.N.M.; Castro, R.V.O.; Santos, R.C.; Ferreira, L.P.; Damásio, R.A.P.; Vital, B.R. 2014. Potential energy of Eucalyptus Sp. wood according to age and different Genetic materials. Rev Arvore 38(2): 375-381. https://doi.org/10.1590/S0100-67622014000200019

Castro, A.F.N.M.; Castro, R.V.O.; Carneiro, A.C.O.; Santos, R.C.; Carvalho, A.M.M.L.; Trugilho, P.F.; Melo, I.C.N.A. 2016. Correlations between age, wood quality and charcoal quality of Eucalyptus clones. Rev Arvore 40(3): 551-560. https://doi.org/10.1590/0100-67622016000300019

Câmara de Comercialização de Energia Elétrica. CCEE. 2019. Informações de Mercado Mensal Contabilização de abril de 2019. CCEE: São Paulo, Brasil. https://www.ccee.org.br/portal/faces/pages_pu- 
blico/o-que-fazemos/infomercado?showFlag=F\& afrLoop=895960388849199\#!\%40\%40\%3F afrLoop\%3D895960388849199\%26showFlag\%3DF\%26_adf.ctrl-state\%3D6cj9mtt5q_9

Centro de Gestão e Estudos Estratégicos. CGEE. 2015. Modernização da produção de carvão: Subsídios para revisão do plano siderurgia. CGEE: Brasília, Brasil. https://www.cgee.org.br/documents/10195/734063/ Carvao_Vegetal_WEB_02102015 10225.PDF/a3cd6c7c-5b5b-450a-955b-2770e7d25f5c?version=1.3

CIFlorestas. 2018. Cotações. Centro de Inteligência em Florestas: Viçosa, Minas Gerais, Brasil. http://www.ciflorestas.com.br/cotacoes.php

De Oliveira Vilela, A.; Lora, E.S.; Quintero, Q.R.; Vicintin, R.A.; Souza, T.P.S. 2014. A new technology for the combined production of charcoal and electricity through cogeneration. Biomass Bioenerg 69: 222-240. https://doi.org/10.1016/j.biombioe.2014.06.019

Deboni, T.L.; Simioni, F.J.; Brand, M.A.; Lopes, G.P. 2019. Evolution of the quality of forest biomass for energy generation in a cogeneration plant. Renew Energy 135: 1291-1302. https://doi.org/10.1016/j. renene.2018.09.039

DIN. EN. 2010a. Solid biofuels - Determination of moisture content - Oven dry method - Part 2: Total moisture - Simplified method. DIN. EN 14774-2. 2010. CEN: Berlin, Germany. 9p.

DIN. EN. 2010b. Determination of calorific value. DIN. EN 14918. 2010b. CEN: Berlin, Germany. 63p.

DIN. EN. 2010c. Solid biofuels - Determination of bulk density. DIN. EN 15103. 2010c. CEN: Berlin, Germany. 14p.

DIN. EN. 2012. Solid biofuels - Determination of ash content. DIN. EN 14775. 2012. CEN: Berlin, Germany. 12 p.

Do, T.X.; Lim, Y. Il; Yeo, H.; Lee, U. Do; Choi, Y. Tai; Song, J. Hun. 2014. Techno-economic analysis of power plant via circulating fluidized-bed gasification from woodchips. Energy 70: 547-560. https://doi.org/10.1016/j.energy.2014.04.048

ENERDATA. 2018. Global Energy Statistical Yearbook 2018. ENERDATA S.A: Grenoble, France. https://www.enerdata.net/publications/reports-presentations/2018-world-energy-trends-projections.html

Empresa de Pesquisa Energética. EPE. 2017. Leilão A-6 de 2017 - Preços de Referência dos Combustíveis para as Usinas Termelétricas. EPE: Rio de Janeiro, Brasil. https://www.epe.gov.br/sites-en/publicacoes-dados-abertos/publicacoes/PublicacoesArquivos/publicacao-121/EPE-DEE-IT-053_A-6_2017_r1.pdf

Empresa de Pesquisa Energética. EPE. 2018. Plano Decenal de Expansão de Energia 2027. EPE: Rio de Janeiro, Brasil. http://www.epe.gov.br/sites-pt/publicacoes-dados-abertos/publicacoes/Documents/PDE\%20 2027_aprovado_OFICIAL.pdf

Fernández, R.G.; García, C.P.; Lavín, A.G.; Bueno, J.L. 2012a. Characterization of spanish biomass wastes for energy use. Bioresour Technol 103(1): 249-258. https://doi.org/10.1016/j.biortech.2011.10.004

Fernández, R.G.; García, C.P.; Lavín, A.G.; De las Heras, J.L.B. 2012b. Study of main combustion characteristics for biomass fuels used in boilers. Fuel Process Technol 103: 16-26. https://doi.org/10.1016/j. fuproc.2011.12.032

Instituto Acende Brasil. IAB. 2015. Avaliação do potencial de geração de eletricidade a partir de madeira no Brasil. IAB: São Paulo, Brasil. https://www.inputbrasil.org/wp-content/uploads/2017/08/Relatorio_Avaliacao-do-potencial-de-geracao-de-eletricidade-a-partir-da-madeira-no-Brasil.pdf

Indústria Brasileira de Árvores. IBÁ. 2020. Annual Report 2020 . IBÁ: São Paulo, Brasil. https://iba. org/datafiles/publicacoes/relatorios/relatorio-iba-2020.pdf

Instituto Brasileiro de Geografia e Estatística. IBGE. 2017. Produção da Extração Vegetal e da Silvicultura - Área total existente em 31/12/2017 dos efetivos da silvicultura, por espécie florestal. IBGE: Brasília, Brasil. https://sidra.ibge.gov.br/pesquisa/pevs/tabelas 
ICAVI. 2019. Indústria de Caldeiras Vale do Itajaí S/A. Pouso Redondo, Santa Catarina, Brasil. https://www.icavi.ind.br/en/home-en/

Ignacio, L.H.S.; Almeida Santos, P.E.; Duarte, C.A.R. 2019. An experimental assessment of Eucalyptus urosemente energy potential for biomass production in Brazil. Renew Sust Energ Rev 103: 361-369. https://doi.org/10.1016/j.rser.2018.12.053

Lamas, W.Q.; Giacaglia, G.E.O. 2013. The Brazilian energy matrix: evolution analysis and its impact on farming. Energ Policy 63: 321-327. https://doi.org/10.1016/j.enpol.2013.09.009

Lora, E.S.; Andrade, R.V. 2009. Biomass as Energy Source in Brazil. Renew Sust Energ Rev 13(4): 777 788. https://doi.org/10.1016/j.rser.2007.12.004

Magalhães, M.A.D.; Carneiro, A.D.C.O.; Vital, B.R.; Silva, C.M.S.D.; Souza, M.M.D.; Fialho, L. D.F. 2017. Estimates of mass and energy of different genetic material Eucalyptus. Rev Arvore 41(3): e410302. https://doi.org/10.1590/1806-90882017000300002

Martinez, C.L.M.; Sermyagina, E.; Carneiro, A.D.C.O.; Vakkilainen, E.; Cardoso, M. 2019. Production and characterization of coffee-pine wood residue briquettes as an alternative fuel for local firing systems in Brazil. Biomass Bioenergy 12: 70-77. https://doi.org/10.1016/j.biombioe.2019.02.013

Miranda, M.A.D.S.; Ribeiro, G.B.D.D.; Valverde, S.R.; Isbaex, C. 2017. Eucalyptus Sp. woodchip potential for industrial thermal energy production. Rev Arvore 41(6): e410604. https://doi.org/10.1590/180690882017000600004

Morato, M.M.; Costa Mendes, P.R.; Cani, A.A.; Normey-Rico, J.E.; Bordons, C. 2018. Electrical power and energy systems future hybrid local energy generation paradigm for the brazilian sugarcane industry scenario. Int j Elec Power 101: 139-150. https://doi.org/10.1016/j.ijepes.2018.03.024

Nzotcha, U.; Kenfack, J. 2019. Contribution of the wood-processing industry for sustainable power generation: viability of biomass-fuelled cogeneration in sub-saharan africa. Biomass Bioenerg 120: 324-331. https://doi.org/10.1016/j.biombioe.2018.11.015

Saidur, R.; Abdelaziz, E.A.; Demirbas, A.; Hossain, M.S.; Mekhilef, S. 2011. A review on biomass as a fuel for boilers. Renew Sust Energ Rev 15(5): 2262-2289. https://doi.org/10.1016/j.rser.2011.02.015

Statsoft. I.N.C. 2007. Statistica data analysis software system - version 8.0. Statsoft. I.N.C:Tulsa, USA.

Stoppato, A. 2012. Energetic and economic investigation of the operation management of an organic rankine cycle cogeneration plant. Energy 41(1): 3-9. https://doi.org/10.1016/j.energy.2011.09.033

Vital, B.R. 1984. Boletim técnico $n^{\circ} 1$ - Métodos de determinação de densidade da madeira. Sociedade de Investigações Florestais: Viçosa, Minas Gerais, Brasil. 